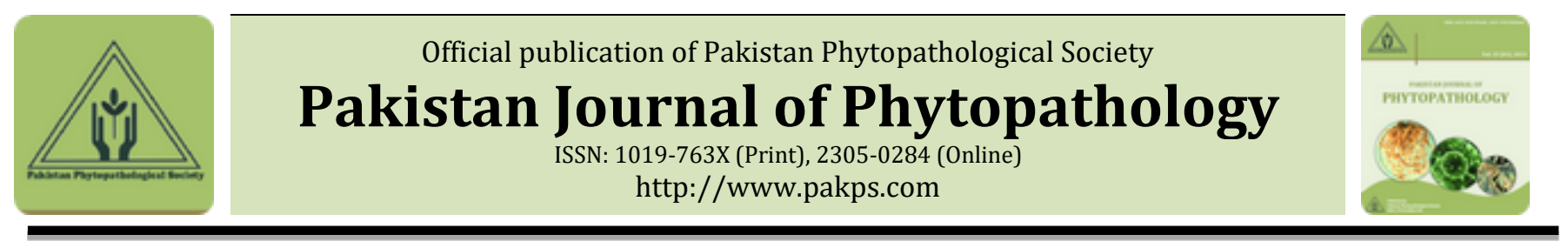

\title{
EVALUATION OF CYTROL AND REVUS FUNGICIDES AGAINST LATE BLIGHT OF POTATO
}

\author{
aNadeem Shad*, a Irfan Liaquat, a aqra H. Khan, bisar Hussain, cGulraze A. Liaqat, aArshad Javaid \\ a Institute of Agricultural Sciences, University of the Punjab, Lahore, Pakistan. \\ b Tara Crop Sciences (Pvt.) Ltd., Pakistan. \\ c Tara Imperial Industries (Pvt.) Ltd., Pakistan.
}

\section{A B S T R A C T}

A field experiment was carried out in 2019 to assess the efficacy of two fungicides namely cytrol 75\% WP (thiophanate methyl 35\% + chlorothalonil 40\%) and revus 240 SC (mandipropamid) to control late blight of potato caused by Phytophthora infestans, under field conditions. The experiment was carried out in a randomized complete block design. There were four treatments viz. control, cytrol @ $500 \mathrm{~g} \mathrm{acre}^{-1}$, cytrol @ $600 \mathrm{~g} \mathrm{acre}^{-1}$ and revus $240 \mathrm{~mL}$ acre $^{-1}$. Data regarding disease incidence and disease control were recorded on $3^{\text {rd }}, 5^{\text {th }}$ and $7^{\text {th }}$ days after spray. On day $7^{\text {th }}$, the highest disease incidence (74\%) was recorded in control. All three fungicide treatments significantly reduced disease incidence. Cytrol @ 500 and $600 \mathrm{~g} \mathrm{acre}^{-1}$ treatments reduced the disease incidence to $28 \%$ and $25 \%$, showing $62 \%$ and $66 \%$ disease control potential, respectively. Likewise, application of revus $240 \mathrm{~mL}$ acre-1 reduced disease incidence to $28 \%$ exhibiting $62 \%$ disease control potential over control. This study concludes that cytrol @ 500 g acre1 and revus $240 \mathrm{~mL}$ acre ${ }^{-1}$ can effectively control late blight of potato under field conditions.

Keywords: Cytrol, Disease management, Late blight of potato, Revus.

\section{INTRODUCTION}

Late blight of potato continues to be the main biotic constraint all the time. It is caused by Phytophthora infestans, a fungus like microorganism that belongs to the oomycetes (Ah-Fong et al., 2017). It is considered a nearly obligate parasite with a narrow host range (Leesutthiphonchai and Judelson, 2018). This pathogenic fungus generally produces oospores, the reproductive structures that are endogenously dormant, can tolerate extremely adverse conditions and remain viable in the soil for at least 3 years (Kiiker et al., 2018). In the mid-nineteenth century, it was best known for its role in precipitating the Irish potato famine that had tremendous effects on human history resulting in population displacement and famine (Pais al., 2018). It is

Submitted: October 15, 2020

Revised: December 01, 2020

Accepted for Publication: December 03, 2020

* Corresponding Author:

Email: nadeem.iags@pu.edu.pk

(C) 2017 Pak. J. Phytopathol. All rights reserved. still remaining a major constraint to potato production, the fourth largest food crop and a critical alternate to the major cereal crops for feeding the world's population (Chung et al., 2019). The pathogen can induce 100\% yield losses under favorable epidemic conditions in Pakistan (Raza et al., 2020). It is not only causing economic losses but also damages the quantity and quality of the crop. Symptoms of the disease can be seen on tubers, stems and leaves in the form of water-soaked light to dark brown spots with slightly depressed areas (Gold et al., 2020a). Mild temperature and high humidity are the key factors for disease development and under optimal conditions, it can destroy a field in a few days (Gold et al., 2020b).

Management of this devastating pathogen is challenged by its behavior and remarkable speed of adaption to control strategies (Ortiz et al., 2019). Therefore, the development of reliable management tactics is the immediate objective of many researchers. Presently, the most authentic approach is the use of chemical fungicides that has enabled the potato cultivars to grow 
prudently in those environments in which late blight is problematic (Khadka et al., 2020). Fungicides namely metalaxyl, cymoxanil, ridomil gold, difenoconazole, fenamidone and mancozeb are used commonly and found to be very effective to overcome the pathogen stress (Mulugeta et al., 2019; Peerzada et al., 2020). The present study was undertaken to check the efficacy of cytrol 75\% WP (thiophanate methyl 35\% + chlorothalonil 40\%) and revus 240 SC (mandipropamid) against the late blight disease of potato.

\section{MATERIALS AND METHODS}

Field trial: A field experiment was conducted in January 2019 at the village Atari Ajeet Singh, Kot Radha Kishan, Kasur, Pakistan. A potato field infected with late blight disease was selected for chemical control of the disease using fungicides cytrol $75 \%$ WP and revus 240 SC. The experiment was carried out using a randomized complete block design with four treatments and three replications. Each experimental plot was measured $7 \times 10 \mathrm{~m}^{2}$. Treatments included a control, cytrol @ 500 g acre $^{-1}$, cytrol @ $600 \mathrm{~g} \mathrm{acre}^{-1}$ and revus $240 \mathrm{~mL}$ acre ${ }^{-1}$.

A simple manual spray machine of twenty liters was selected for the spray of fungicide. The machine was filled with five liters of water and sprayed in the control plot for calibration of machine. After sprayed in the control plot, the remaining water was measured with a measuring cylinder and the quantity of water used for one plot was measured. After calculation of doses, the measured dose was put in a spray machine along with three liters of water, thoroughly mixed and then applied in each plot. After application of each treatment, the machine was washed thoroughly and used for next treatment. In control plots, no fungicide was applied. The data regarding disease incidence were recorded randomly from three places from each plot with the help of $1 \times 2 \mathrm{~m}^{2}$ quadrate. The data were recorded before application of fungicides as well as on $3^{\text {rd }}$, $5^{\text {thand }} 7$ th day after application of fungicides. The quadrate was thrown randomly and the total number of plants as well as infected plants was counted. The average of three readings was taken, then grand average of both replications was calculated. Disease incidence (DI) was calculated by dividing the number of infected plants by the total number of plants and multiply by a hundred according to the given formula:

$$
\text { Disease incidence }(\%)=\frac{\text { No. of infected plants }}{\text { Total no. of plants }} \times 100
$$

Percentage control was calculated by using the following formula:

$$
\text { Disease control }(\%)=\frac{\text { DI in control - DI in treatmment }}{\text { DI in control }} \times 100
$$

\section{STATISTICAL ANALYSIS}

All the data were analyzed by ANOVA followed by application of LSD test at $P \leq 0.05$ using software Statistix 8.1.

\section{RESULTS AND DISCUSSION}

There was $17-18.3 \%$ incidence of late blight of potato in different field plots prior to application of fungicides. The disease incidence was continuously increased to 42,64 and $74 \%$ in control plots after 3, 5 and 7 days of start of the experiment respectively. By contrast, in all the fungicide treatment plots, generally, there was not any significant increase in disease incidence after 3 and 5 days of spray with respect to pre-treatment data. After 7 days of spray, there was a significant increase in disease incidence in all the fungicide treatments as compared to pre-treatment data. However, at all the three-time intervals, disease incidence in fungicide treated plants was significantly lower as compared to corresponding control treatments (Figure 1). There was
53,59 and $59 \%$ disease control after 3 days, 69,72 and $64 \%$ after 5 days and 62,66 and $62 \%$ after 7 days of spray due to application of cytrol @ $500 \mathrm{~g} \mathrm{acre}^{-1}$, cytrol @ $600 \mathrm{~g} \mathrm{acre}^{-1}$ and revus $240 \mathrm{~mL} \mathrm{acre}^{-1}$, respectively (Figure 2).

The present findings are in confirmation of Kumar et al. (2020) where a $100 \%$ growth inhibition of $P$. infestans was recorded at a higher concentration of $400 \mathrm{ppm}$ of metalaxyl. Earlier, Humza et al. (2017) evaluated the antifungal potential of six different fungicides against the $P$. infestans causing infections on two strains of tomato in field conditions. The findings were in contrast to the present studies where revus was found to be the least effective one in controlling the pathogen growth. Lal et al. (2017) applied mancozeb 64\% WP and metalaxyl at the same time before the symptom's appearance of late blight of potato followed by the onset of disease after seven days. There was a distinct difference between the spray utilization, prior to the appearance of disease symptoms that significantly affected 
the pathogen incidence on potato crop. Fungicides such as cymoxanil, mancozeb $72 \mathrm{WP}$, fenamidone, dimethomorph, difenoconazole, propineb and chlorothalonil were checked for their antifungal potential against the P. infestans.

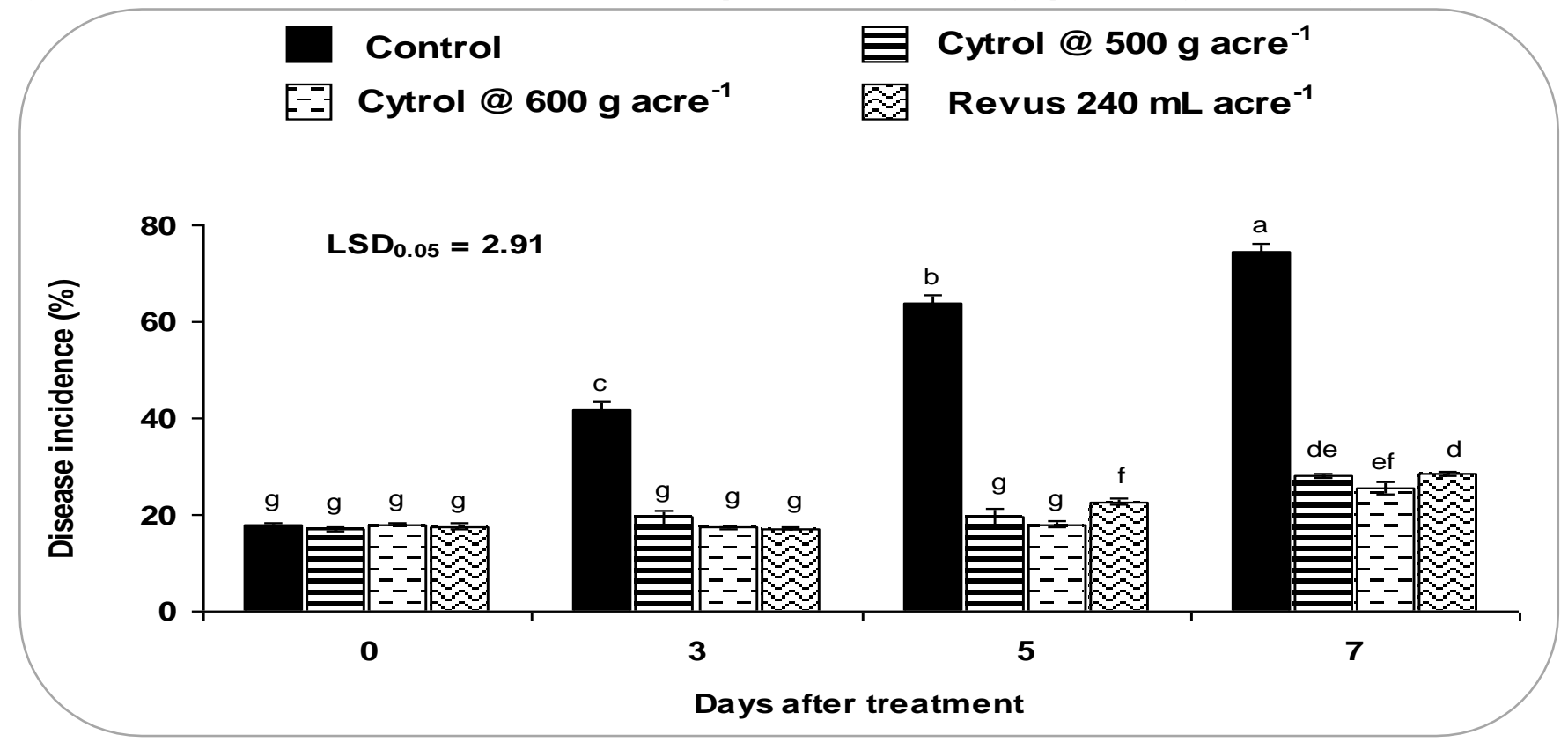

Figure 1. Effect of cytrol 75\% WP and revus 240 SC fungicides on incidence of late blight of potato. Vertical bars show standard errors of means of three replicates. Values with different letters at their tops show significant difference $(P \leq 0.05)$ as determined by LSD test.

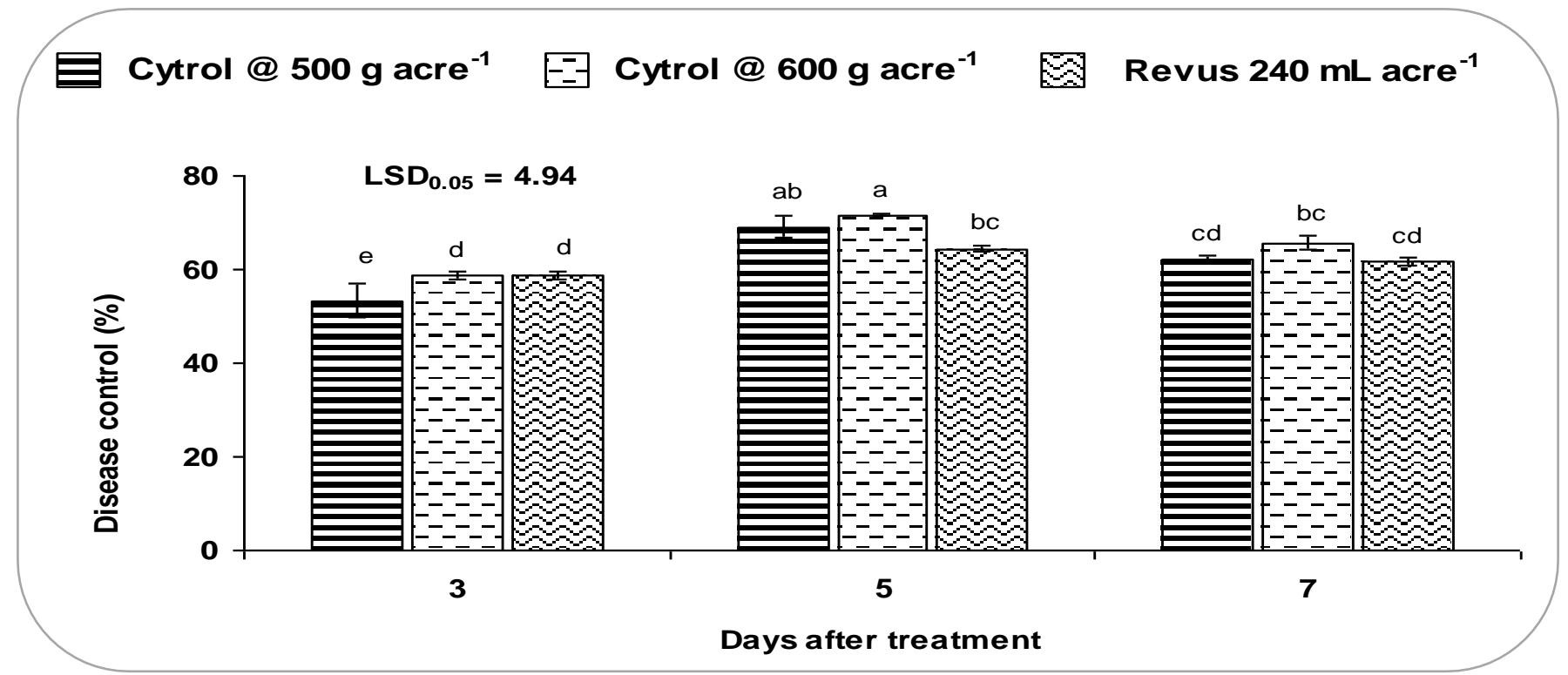

Figure 2. Percentage control of late blight of potato due to applications of cytrol 75\% WP and revus 240 SC fungicides. Vertical bars show standard errors of means of three replicates. Values with different letters at their tops show significant difference $(P \leq 0.05)$ as determined by LSD test.

The results showed an excellent inhibitory potential of all the tested fungicides at higher concentration of 2000 $\mu \mathrm{g} / \mathrm{mL}$ whereas, 500 and $1000 \mu \mathrm{g} / \mathrm{mL}$ were moderately effective and the lower concentrations of 100 and 200 $\mu \mathrm{g} / \mathrm{mL}$ were the least effective (Peerzada et al., 2020).
Previously, many studies were carried out for the effective management of potato late blight pathogen through the use of metalaxyl and mancozeb. However, a limited literature is available on the use of cytrol $75 \%$ WP (thiophanate methyl 35\% + chlorothalonil 40\%) and 
revus 240 SC (mandipropamid) against $P$. infestans. However, the applications of these two fungicides were carried out against different fungal pathogens with a successful outcome. Recently, many fungal diseases such as Alternaria blight, Alternaria leaf spot and White rust caused by Alternaria cucumerina, A. brassicae and Albugo candida have been controlled through the application of cytrol (Asif et al., 2017; Subhani et al., 2018; Khan et al., 2020). Likewise, Ravinder et al. (2020) tested three fungicides namely revus, hexaconazole and mancozeb for the effective control of $A$. solani responsible for early blight of tomato. The present study concludes that cytrol and revus are very effective against the late blight pathogen P. infestans.

\section{REFERENCES}

Ah-Fong, A. M., K. S. Kim and H. S. Judelson. 2017. RNAseq of life stages of the oomycete Phytophthora infestans reveals dynamic changes in metabolic, signal transduction, and pathogenesis genes and a major role for calcium signaling in development. BMC genomics, 18: 198.

Asif, M., M. Atiq, S. T. Sahi, S. Ali, A. Nawaz, Y. Ali, A. Subhani and A. Saleem. 2017. Effective management of white rust (Albugo candida) of rapeseed through commercially available fungicides. Pakistan Journal of Phytopathology, 29: 233-237.

Chung, I.-M., B. Venkidasamy, C. P. Upadhyaya, G. Packiaraj, G. Rajakumar and M. Thiruvengadam. 2019. Alleviation of Phytophthora infestans mediated necrotic stress in the transgenic potato (Solanum tuberosum L.) with enhanced ascorbic acid accumulation. Plants, 8: 365.

Gold, K. M., P. A. Townsend, A. Chlus, I. Herrmann, J. J. Couture, E. R. Larson and A. J. Gevens. 2020. Hyperspectral measurements enable presymptomatic detection and differentiation of contrasting physiological effects of late blight and early blight in potato. Remote Sensing, 12: 286.

Gold, K. M., P. A. Townsend, I. Herrmann and A. J. Gevens. 2020. Investigating potato late blight physiological differences across potato cultivars with spectroscopy and machine learning. Plant Science, 295: 110316.

Humza, M., B. Iqbal, M. Nasir, M. Atiq and M. Rana. 2017. In Vivo Evaluation of Fungicides for the Management of Late Blight of Tomato. Journal of Plant Pathology and Microbiology, 8: 2.
Khadka, R. B., B. Chaulagain, S. Subedi, M. Marasini, R. Rawal, N. Pathak, I. P. Gautam, T. R. Chapagain, B. B. Khatri and D. Sharma-Poudyal. 2020. Evaluation of fungicides to control potato late blight (Phytophthora infestans) in the plains of Nepal. Journal of Phytopathology, 168: 245-253.

Khan, A. A., M. T. H. Khan, I. Kanwal, A. Nazir, A. Habib and F. Imran. 2020. Genetic \& biochemical management of Alternaria leaf spot disease of cabbage and cauliflower. The International Journal of Biological Research, 3: 85-101.

Kiiker, R., M. Hansen, I. H. Williams, D. E. Cooke and E. Runno-Paurson. 2018. Outcome of sexual reproduction in the Phytophthora infestans population in Estonian potato fields. European Journal of Plant Pathology, 152: 395-407.

Kumar, V., R. Singh, R. Doharey and S. Kumar. 2020. Evaluation of the effect of different fungicides against Phytophthora infestans (Mont) de Bary (In vitro). Journal of Pharmacognosy and Phytochemistry, 9: 1935-1942.

Lal, M., S. Yadav, S. Sharma, B. Singh and S. Kaushik. 2017. Integrated management of late blight of potato. Journal of Applied and Natural Science, 9: 1821-1824.

Leesutthiphonchai, W. and H. S. Judelson. 2018. A MADSbox transcription factor regulates a central step in sporulation of the oomycete Phytophthora infestans. Molecular Microbiology, 110: 562-575.

Mulugeta, T., K. Abreha, H. Tekie, B. Mulatu, M. Yesuf, E. Andreasson, E. Liljeroth and E. Alexandersson. 2019. Phosphite protects against potato and tomato late blight in tropical climates and has varying toxicity depending on the Phytophthora infestans isolate. Crop Protection, 121: 139-146.

Ortiz, O., R. Nelson, M. Olanya, G. Thiele, R. Orrego, W. Pradel, R. Kakuhenzire, G. Woldegiorgis, J. Gabriel and J. Vallejo. 2019. Human and technical dimensions of potato integrated pest management using farmer field schools: International Potato Center and partners' experience with potato late blight management. Journal of Integrated Pest Management, 10: 4.

Pais, M., K. Yoshida, A. Giannakopoulou, M. A. Pel, L. M. Cano, R. F. Oliva, K. Witek, H. Lindqvist-Kreuze, V. G. Vleeshouwers and S. Kamoun. 2018. Gene expression polymorphism underpins evasion of host immunity in an asexual lineage of the Irish 
potato famine pathogen. BMC evolutionary biology, 18: 93.

Peerzada, S., H. Viswanath and K. Bhat. 2020. In-vitro studies on effect of fungicides against mycelial growth and sporangial germination of Phytophthora infestans (Mont) de Bary) causing late blight of potato. International Journal of Chemical Studies, 8: 2069-2075.

Ravinder, N.S., K. Raj, R.K. Chugh and R. Sangwan. 2020. Evaluation of plant extracts, fungicides and bioagents against early blight disease of tomato incited by Alternaria solani under in vitro and field conditions. International Journal of Current
Microbiology and Applied Sciences, 9:1914-1920.

Raza, W., M. U. Ghazanfar, L. Sullivan, D. E. Cooke and L. R. Cooke. 2020. Mating Type and Aggressiveness of Phytophthora infestans (Mont.) de Bary in Potato-Growing Areas of Punjab, Pakistan, 20172018 and Identification of Genotype 13_A2 in 2019-2020. Potato Research: 1-15.

Subhani, A., M. Atiq, N. A. Rajput, M. R. Bashir, M. Asif, S. Kauser, Y. Ali, A. Hameed, N. Muhammad and K. Mazhar. 2018. Antifungal potential of commercially available fungicides against Alternaria blight of Brassica. Pakistan Journal of Phytopathology, 30: 53-58.

\begin{tabular}{lll}
\hline Contribution of Authors: & & \\
Nadeem Shad & $:$ & Supervised the work and write manuscript \\
Irfan Liaquat & $:$ & Carried out experimental work \\
Iqra H. Khan & $:$ Wrote the paper \\
Nisar Hussain & $:$ Provided the research materials \\
Gulraze A. Liaqat & $:$ Helped in execution of field trial \\
Arshad Javaid & $:$ Prepared graphs and analyzed the data statistically
\end{tabular}

